\title{
Protein Enrichment of Cactus Pear (Opuntia ficus - indica Mill) Using Saccharomyces cerevisiae in Solid-State Fermentation
}

\author{
Lúcia de Fátima Araújo ${ }^{1}$, Ariosvaldo Nunes Medeiros ${ }^{2}$, Américo Perazzo Neto $^{2}$, Líbia de \\ Sousa Conrado Oliveira ${ }^{3}$ and Flávio Luiz Honorato da Silva ${ }^{3 *}$ \\ ${ }^{1}$ Empresa Estadual de Pesquisa Agropecuária da Paraíba (EMEPA/PB). ${ }^{2}$ Departamento de Agronomia e Zootecnia; \\ Centro de Ciências Agrárias;Universidade Federal da Paraíba - UFPB; Areia - Brasil. ${ }^{3}$ Departamento de \\ Engenharia Química; Centro de Ciências e Tecnologia; Universidade Federal de Campina Grande - UFCG; \\ Avenida Aprígio Veloso, 882; Bodocongó; flhs@deq.ufcg.edu.br; 58109-970; Campina Grande - PB - Brasil
}

\begin{abstract}
The microbial protein bioconversion of cactus pear by yeast in solid medium was studied. Three cultivation variables used were: inoculum's concentrations (5, 10 and $15 \%)$, substrate layer thickness (2, 4 and $6 \mathrm{~cm})$ and temperature $\left(30,34\right.$ and $\left.38{ }^{\circ} \mathrm{C}\right)$. The rate of dry matter production and total protein were determined. Results obtained were variance analysis, gross energy and in vitro dry matter digestibility. The maximum protein amount achieved for the conditions studied in the present work was higher than $26 \%$, which was compatible or greater than those of conventional concentrates of protein supplements used for animal feed. The protein concentrate of cactus pear had a higher in vitro digestibility index (95.8\%) and did not show any changes in the gross energy value when compared to that of the cactus pear in natura.
\end{abstract}

Key words: Protein enrichment, solid-state fermentation, cactus pear, yeast

\section{INTRODUCTION}

The production of fodder in the Semi-arid region is provoked by the irregular distribution of the rain and associated to a deficiency in pasturing, resulting in low availability of fodder during the drought season. This results the use of commercial concentrates during this period as a protein supplement to suppress the nutritional necessities of the herd. But due to the frequent price rise of the protein supplement used in feeding the animals, it is becoming a non-economical activity for the breeders. Thus, this challenge has stimulated the interest in utilizing non- conventional supplies in the Animal Alimentation Industry in Brazil.

Within the products that can be a substitute for the protein supplement, the microorganisms (algae, bacteria, fungi and yeasts) are considered a source of cell protein with an elevated protein content besides possessing a rapid growth rate and the possibility of being cultured on diverse substrates. Of the vegetation available in the region that presents favorable characteristics to develop these microorganisms, cactus pear seems promising. This cactus is one of the most promissory from the Semi-arid region, by presenting the largest part of alimentation furnished to the animals during the

\footnotetext{
* Author for correspondence
} 
drought. This increases the availability of fodder and alleviates the problems of the water supplement to these animals. This is also rich in minerals, calcium, iron and vitamin A. It presents an elevated texture of soluble carbohydrates besides presenting a high coefficient of digestibility of the dry matter and high productivity (Santos et al., 1992; Teixeira et al., 1999). The largest area planted with cactus pear in the world is in the Northeastern Region of Brazil (approximately 550 hectares). Although it has characteristics that are adapted to the adverse conditions of the region, it presents some limitations in relation to proteins and minerals, showing itself as inferior to other fodder cultures. With the cultivation of microorganisms such as fungi, this vegetable can increase its nutritional value being added to microbial proteins, salts like phosphate, potassium and calcium besides containing some vitamins from the complex B, important growth factors for the animals (Villas Boas and Esposito, 2000).

Solid-state fermentation (SSF) is a microbial process in that a solid material is used as the substrate or the inert support of microbial cell growing on it. It embraces the growth of microorganisms on water-insoluble substrate in the absence of free water (Mitchell et al., 1999; Sato and Sudo, 1999; Pandey et al., 2001).

The objective of this work was to study the effects of variables inoculum concentrates, temperature and layer thickness over the protein increase and dry matter of cactus pear in solid-state fermentation process.

\section{MATERIALS AND METHODS}

The microorganisms used for protein enrichment of substrate in study was Saccharomyces cerevisiae, commercial type fresh biological yeast, with moisture content of $70 \%$ in a wet base and crude protein content of $45 \%$. To prepare the inoculum, the microorganism was added directly to the substrate at levels of 5,10 , and $15 \%$ in relation to the weight, as shown in Table 1.

The substrate used was cactus pear (Opuntia ficusindica Mill) derived from the experimental field of Donana Farm. After harvesting the material, the racquets of cactus pear in natura were ground in a fodder type Nogueira $\mathrm{N}^{\circ} 2$.

SSF was carried out by taking $1 \mathrm{~kg}$ of substrate in aluminum trays $(60 \mathrm{~cm}$ diameter and $12 \mathrm{~cm}$ high and fermenting at 30,34 , and $38^{\circ} \mathrm{C}$ (Table 1).

After the final fermentation process, the samples for analyses were weighed and put in trays of aluminum paper $\mathrm{N}^{\circ} 20$ to realize a pre drying in an oven at $55^{\circ} \mathrm{C}$ for $72 \mathrm{~h}$. The samples, afterwards, were weighed, grinded in a mill type Willy, with mesh 40, conditioned in glass flasks closed hermetic and sent to the Nutritional and Animal Alimentation Laboratory of the Zootecnia Department at CCA from UFPB for the chemical bromatological analyses and digestibility in vitro of the dry matter. Dry matter, gross energy and moisture content were determined according to the recommendations of AOAC (1984). To determine the crude protein in the dry matter, micro Kjeldahl method was used (AOAC, 1984). To determine the digestibility in vitro of the dry matter, the technique used was the two stages proposed by Tilley and Terry and described by Silva (1998).

Table 1 presents the origin of the factorial design $2^{3}$, with the real levels in parenthesis.

Table 1- Factorial design $2^{3}$

\begin{tabular}{|c|c|c|c|}
\hline Experiment & C & $\mathbf{T}$ & $\mathbf{L}$ \\
\hline 1 & $-1(5 \%)$ & $-1\left(30^{0} \mathrm{C}\right)$ & $-1(2 \mathrm{~cm})$ \\
\hline 2 & $+1(15 \%)$ & $-1\left(30^{0} \mathrm{C}\right)$ & $-1(2 \mathrm{~cm})$ \\
\hline 3 & $-1(5 \%)$ & $+1\left(38^{0} \mathrm{C}\right)$ & $-1(2 \mathrm{~cm})$ \\
\hline 4 & $+1(15 \%)$ & $+1\left(38^{0} \mathrm{C}\right)$ & $-1(2 \mathrm{~cm})$ \\
\hline 5 & $-1(5 \%)$ & $-1\left(30^{\circ} \mathrm{C}\right)$ & $+1(6 \mathrm{~cm})$ \\
\hline 6 & $+1(15 \%)$ & $-1\left(30^{0} \mathrm{C}\right)$ & $+1(6 \mathrm{~cm})$ \\
\hline 7 & $-1(5 \%)$ & $+1\left(38^{0} \mathrm{C}\right)$ & $+1(6 \mathrm{~cm})$ \\
\hline 8 & $+1(15 \%)$ & $+1\left(38^{0} \mathrm{C}\right)$ & $+1(6 \mathrm{~cm})$ \\
\hline 9 & $0(10 \%)$ & $0\left(34^{0} \mathrm{C}\right)$ & $0(4 \mathrm{~cm})$ \\
\hline 10 & $0(10 \%)$ & $0\left(34^{0} \mathrm{C}\right)$ & $0(4 \mathrm{~cm})$ \\
\hline 11 & $0(10 \%)$ & $0\left(34^{0} \mathrm{C}\right)$ & $0(4 \mathrm{~cm})$ \\
\hline
\end{tabular}


The entrance variables (independents) studied were: Initial yeast concentrates (C), Temperature (T), and Layer thickness (L). The response variables (dependents) studied in the protein enrichment were: \% of dry matter (DM) and \% of protein increase (PI).

The determination of protein increase had as its bases the protein value contained in the dry matter of the cactus in natura and was defined as the reason between the protein value of the enriched cactus $(\mathrm{g})$ and the initial value of the crude protein (CP) in natura $(\mathrm{g})$, as shown in Equation 1.

$$
\mathrm{PI}(\%)=\frac{\mathrm{DMxCP}(\text { enrichment })-\mathrm{DMxCP}(\text { in natura })}{\mathrm{DMxCP}(\text { in natura })} \times 100
$$

\section{RESULTS AND DISCUSSION}

Fig. 1 illustrates the kinetic study of the solid-state fermentation with the objective to determine the ideal time of the protein increase.

The curve of $\%$ protein increase (PI) grows with the fermentation time up to $48 \mathrm{~h}$. After this time a decrease in the PI value was noticed within $72 \mathrm{~h}$. This decrease could be attributed to a probable cellular protein denaturation.

With the study of the kinetic fermentation, $48 \mathrm{~h}$ was determined to study the effects of the variables $C, T$, and $L$ over the percentage of the dry matter $(\mathrm{DM})$ and the protein increase of the enriched cactus pear (PI). At this time of fermentation the protein increase presented the highest value (465.3\%) as observed in Fig. 1.

Table 2 presents the results of the responses studied from the 11 experiments (Factorial design).

Results were interpreted through the analysis of variation and regression, using F-Test at a level of 95\% confidence and determination coefficient $\left(\mathrm{R}^{2}\right)$. The linear codified models obtained for the crude protein (PI) and dry matter (DM) are shown through Equations 2 and 3, where the value in bold types are the significant statistical values at a level of $95 \%$ confidence.

In Table 3 the parameters of F-Test are presented, the explained variation coefficient $\left(\mathrm{R}^{2}\right)$ and the calculated $F$ value and listed $F$ value for the responses.

The linear codified models of the $\%$ dry matter $(\mathrm{DM})$ and \% protein increase (PI) were statistical significance at the level of $95 \%$ confidence and were highly predictable, because the calculated $\mathrm{F}$ values times superior to the listed values (Box and Draper, 1987). Statistical significance model could be utilized to build the response surfaces to optimize the process in study. Fig. 2 illustrates the variable influences $\mathrm{C}$ and $\mathrm{T}$ over the \% PI.

Inoculum concentrate (C) presented a positive effect on the response. An increase in the concentration level -1 to the level +1 , maximized the response value (PI). The temperature $(\mathrm{T})$ effect was minimum.

In Fig. 3, the effects of the variables $\mathrm{C}$ and $\mathrm{L}$ over the $\%$ PI are presented.

Yeast concentration (C) presented the most significant effect, influencing the positive response. With the increase in $\mathrm{C}$, there was a significant increase in the response (PI). Temperature (T) and the layer thickness (L), did not present any significant effect at the levels studied. The analysis of the crude protein relates with total nitrogen (inorganic and organic). Yeast can not use the nitrogen from the air. This way an increase of the nitrogen in the substrate doesn't occur during the process, but a decrease of the substrate weight occurs due to the volatilization of $\mathrm{CO}_{2}$ and $\mathrm{H}_{2} \mathrm{O}$ during fermentation. This justified the increase of crude protein. Cactus pear with increased protein can substitute the concentrates used in the conventional animal feed. Comparing the \% of $\mathrm{CP}$, from this study, with the contents recommended by the National Research Council NRC (1989), observing that the protein enriched cactus pear reached protein contents equal or superior to those concentrates of oats $(14.7 \%)$, gross wheat bran (15\%), babaçu pie $(20.5 \%)$, crushed coconut (21.2\%), cotton seed $(23.1 \%)$, pea grains $(23.4 \%)$, babaçu bran $(24 \%)$ and oat bran $(25.8 \%)$.

In relation to the response of \% dry weight (DM) (Figs. 4 and 5), the same profile was observed in the 3 responses of the \% protein increase (PI).

The percentage increase in the dry matter from the fermented product (DM) was due to the growth of the yeast in the substrate. This growth occurred due to the metabolism of the soluble carbohydrate, that produce $\mathrm{CO}_{2}, \mathrm{H}_{2} \mathrm{O}$ and released energy in the form of ATP.

Table 2 showed that the $\%$ dry matter (DM) of cactus pear in natura was 9.3 and the value added to the inoculum (yeast) in the cactus was $30 \%$. During the fermentation process increase in the $\%$ 
DM content was observed witnessing the microbial growth.

Santos (1989) compared three cultures of cactus pear associated to the sorgo ensilage and observed that the animals fed with the those (round, small and giant cactus) didn't get though dry matter and crude protein. However, results obtained in this study suggested a viable alternative to attend the nutritional necessities of the animals during the drought season due to the lack of food in the region.

Table 4 shows the values of digestibility in vitro and the cactus brute energy in natura (average of the 11 experiments).

PI $(\%)=259.01+133.84 C-3.21 \mathrm{~T}-2.11 \mathrm{~L}-$

5.71C.T +1.14C.L + 1.19T.L + 3.69C.T.L
$\mathrm{DM}(\%)=\mathbf{1 2} .50+\mathbf{1 . 8 2 9} \mathrm{C}-0.0013 \mathrm{~T}-0.066 \mathrm{~L}-$ 0.06C.T + 0.05C.L - 0.02 .L + 0.03C.T.L

Digestibility in vitro increased from $78.09 \%$ to $95.8 \%$ (Table 4) in the cactus after SSF. The digestibility coefficient of the cactus pear in natura (Table 4) presented a similar value found by Araujo (1994) and Jardim (1995) for the silage of corn $(75 \%)$ and sorgo $(78 \%)$, respectively after the enriched protein achieved a higher digestibility coefficient than found by Araujo (1994) for the soy bran in natura with a corresponding percentage of $92.3 \%$.

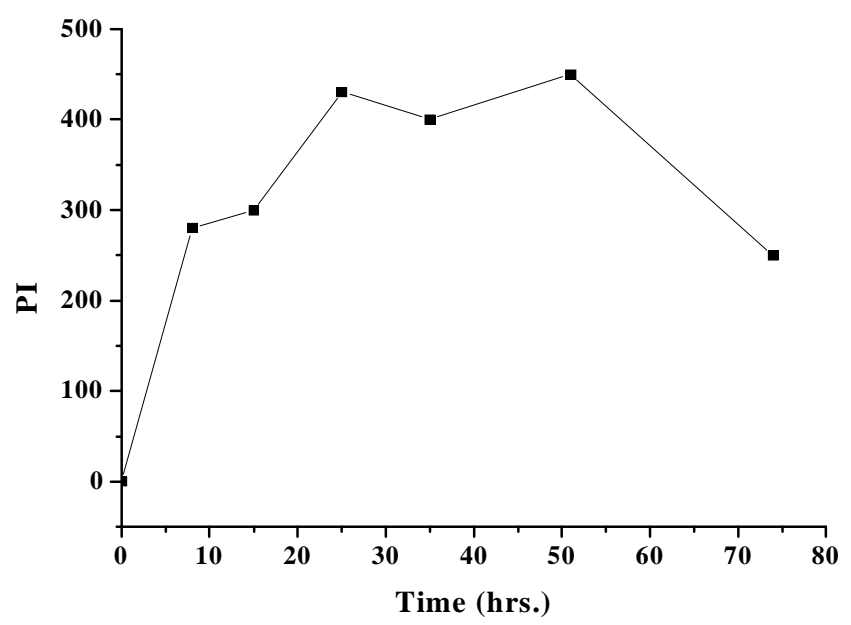

Figure 1 - Kinetic protein increase (PI) with $\mathrm{C}=10 \%, \mathrm{~T}=38^{\circ} \mathrm{C}$ and $\mathrm{L}=4 \mathrm{~cm}$.

Table 2 - Variable values (\%), CP (\%) and PI (\%)

\begin{tabular}{|c|c|c|c|}
\hline Experiment & DM (\%) & $\mathrm{CP}(\%)$ & PI (\%) \\
\hline 1 & 10.74 & 14.88 & 116.8 \\
\hline 2 & 14.49 & 25.48 & 401.0 \\
\hline 3 & 10.96 & 15.25 & 126.4 \\
\hline 4 & 14.34 & 24.33 & 373.4 \\
\hline 5 & 10.62 & 14.94 & 115.3 \\
\hline 6 & 14.42 & 25.01 & 389.3 \\
\hline 7 & 10.63 & 14.93 & 115.3 \\
\hline 8 & 14.33 & 24.75 & 381.2 \\
\hline 9 & 12.31 & 22.51 & 276.0 \\
\hline 10 & 12.25 & 21.26 & 253.4 \\
\hline 11 & 12.43 & 23.75 & 300.6 \\
\hline in natura & 9.30 & 7.93 & - \\
\hline
\end{tabular}


In relation to the gross energy, a small increase was observed in the values of the cactus in natura $(3.52 \mathrm{Kcal} / \mathrm{g})$ in relation to the processed (3.96 $\mathrm{Kcal} / \mathrm{g}$ ). Despite the utilization of carbohydrates by the yeast for its growth, the brute energy content was practically unaltered after the protein enrichment, confirming that the process didn't influence the energetic content negatively.

Table 3 - Analysis of variance (ANOVA)

\begin{tabular}{c|cc}
\hline Parameters & DM & PI \\
\hline Calculated F-value & 1045.5 & 443.1 \\
$\mathrm{R}^{2}$ & 0.99 & 0.98 \\
Calculated F-value /F listed value & 204.2 & 86.5 \\
\hline
\end{tabular}

Table 4 - Digestibility in vitro and gross energy values

\begin{tabular}{ccc}
\hline Variable & in natura & Enrichment average \\
\hline Digestibility Index (\%) & 78.09 & 95.8 \\
Gross energy (Kcal/g) & 3.52 & 3.96 \\
\hline
\end{tabular}

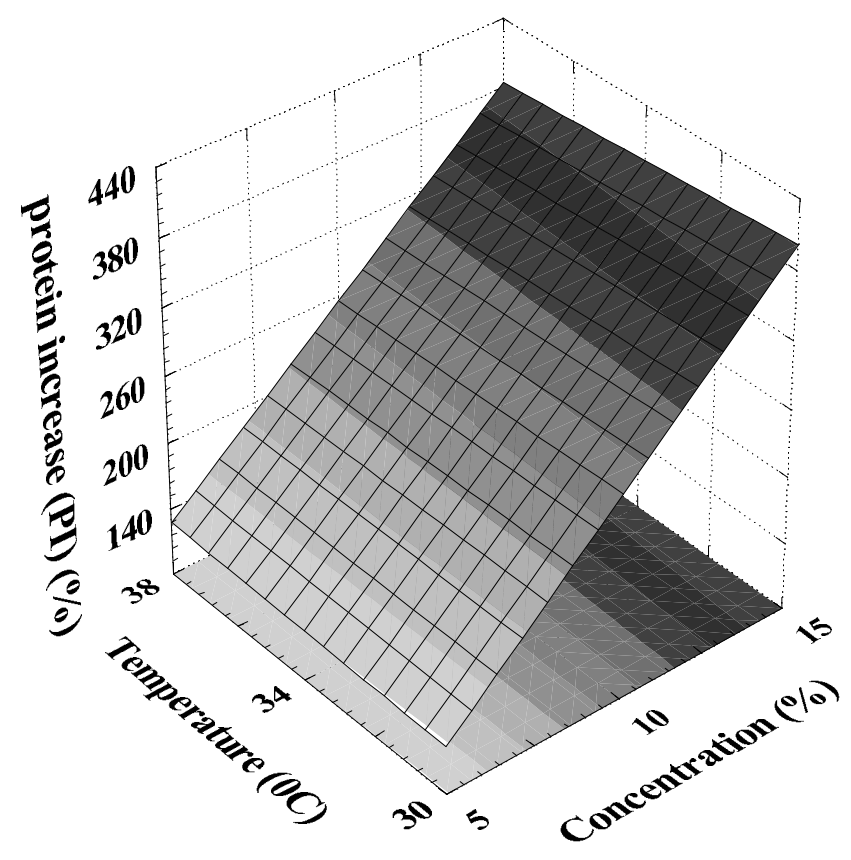

Figure 2 - Temperature influence and concentration over the protein increase (PI), fixed $\mathrm{L}$ in central point $(4 \mathrm{~cm})$. 


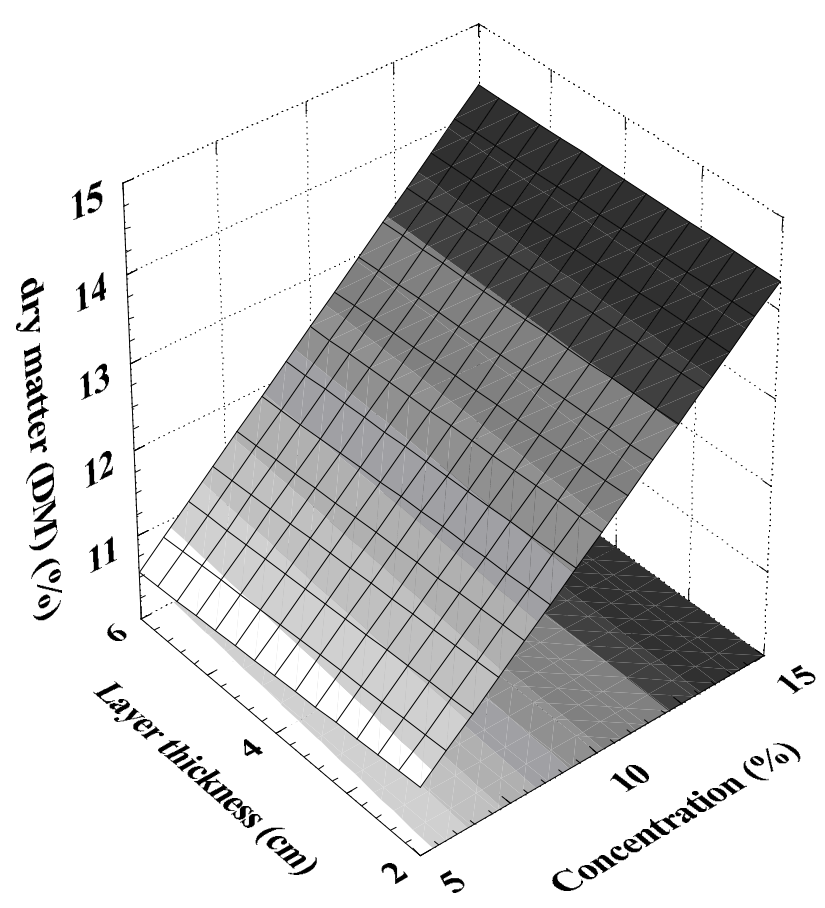

Figure 3 - Layer thickness and concentration influence over the protein increase (PI), fixed $\mathrm{T}$ in central point $\left(34^{0} \mathrm{C}\right)$.

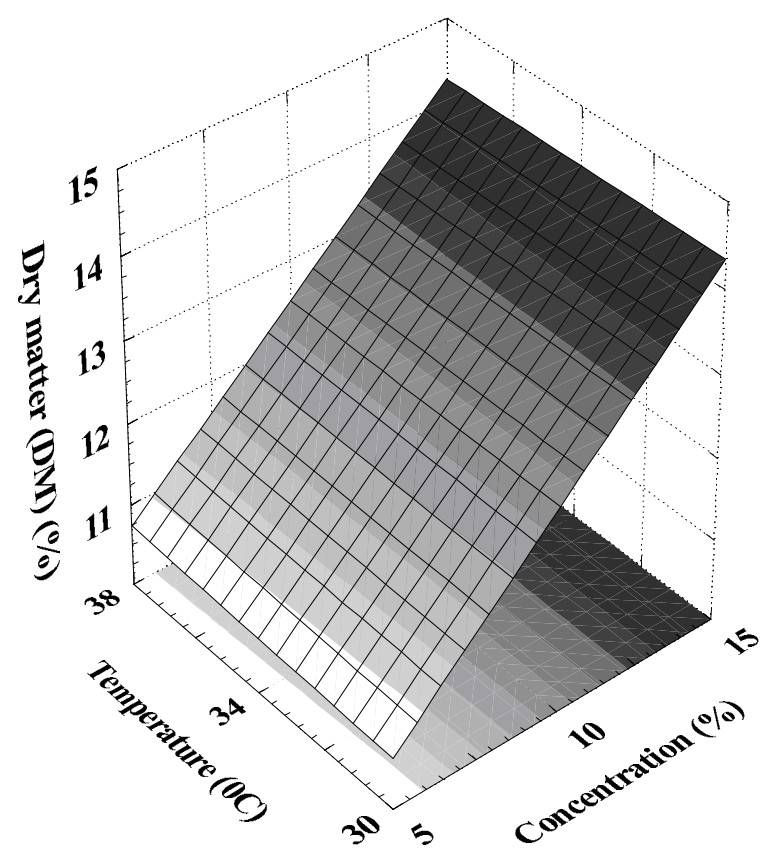

Figure 4 - The influence of temperature and concentration over the \% dry matter (DM), fixed $\mathrm{L}$ in central point $(4 \mathrm{~cm})$. 


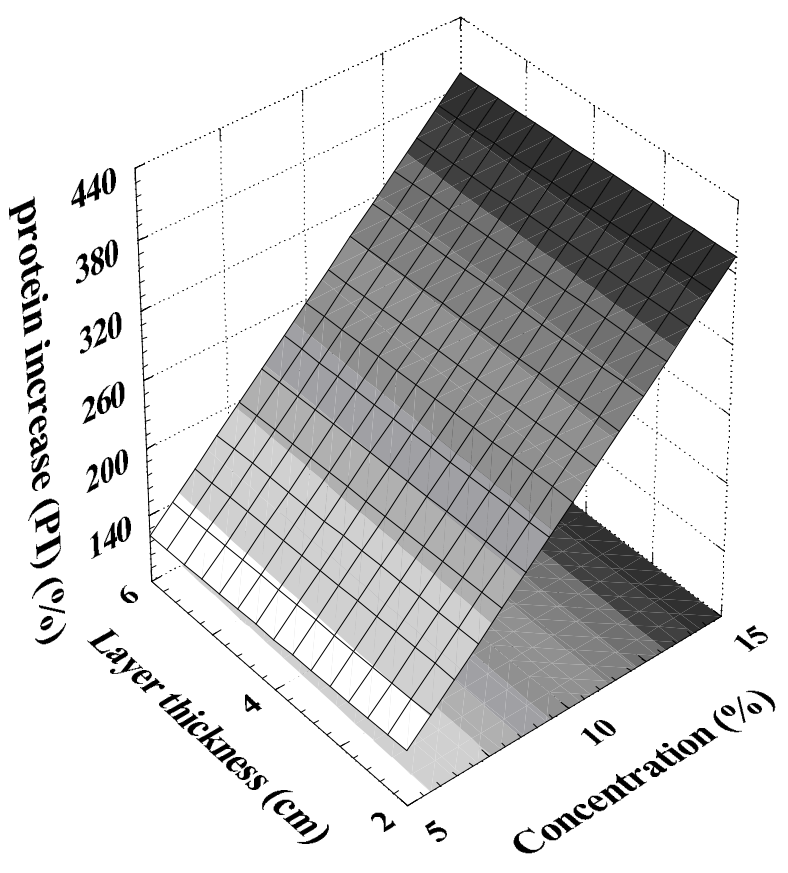

Figure 5 - The influence of concentration and layer thickness over the $\%$ dry matter $(\mathrm{DM})$, fixed $\mathrm{T}$ in central point $\left(34^{0} \mathrm{C}\right)$.

\section{CONCLUSIONS}

The cactus pear protein supplement, obtained in this study, utilized the yeast as an inoculum, constituted in a non conventional feed alternative to the cereal grains that are used in the raising of animals (the so called conventional supplements). The percentage protein increase was up to $400 \%$. Inoculums concentration most influenced the increase positively.

The digestibility in vitro increased from $78.9 \%$ to $95.8 \%$, indicating that there was an excellent absorption of nutrients in the tests realized and that the gross energy was maintained almost unaltered confirming that the process didn't influence the energetic content negatively.

It could be concluded that protein enrichment of cactus pear by SSF in a technical viable option. forrageira cultivada em condições laboratoriais, sob três níveis de concentração do inóculo $(5,10$ e $15 \%)$, espessuras distintas das camadas dos substratos (2, 4 e $6 \mathrm{~cm})$ e temperaturas $(30,34$ e $38^{\circ} \mathrm{C}$ ). Foram analisadas as taxas de produção de matéria seca (MS), proteína bruta (PB), cujos resultados foram submetidos à análise de variância, energia bruta (EB) e digestibilidade in vitro da matéria seca (DIVMS). O valor máximo de teor protéico, alcançado nas condições estudadas nesse trabalho, foi superior a $26 \%$, sendo esse teor compatível ou maior do que os concentrados convencionais utilizados como suplemento protéico para a ração animal. O concentrado protéico da palma obteve um alto índice de digestibilidade in vitro $(95,8 \%)$ e não apresentou grande alteração no valor da energia bruta se comparada com a palma in natura.

\section{RESUMO}

A bioconversão da proteína microbiana através da levedura em meio sólido, foi estudada em palma 


\section{REFERENCES}

Araújo, L. F. (1994), Estudo da composição química bromatológica e da digestibilidade in vitro de alimentos utilizados pelos animais, no Cariri Oriental da Paraíba. MsC. Dissertation, UFCG, Areia, Brazil.

AOAC (1984), Official methods of analysis of the association of official agricultural chemist Washington : Ed. 12.

Box, G. E. and Draper, N. R. (1987), Empirical model building and response surfaces. New York: Wiley.

Jardim, V. R. (1995), Curso de Bovinocultura. 4. ed. Campinas : Instituto Campineiro de Ensino Agrícola.

Mitchell, D. A.; Pandey, A.; Sangsurasak, P. and Krieger, N. (1999), Scale-up for packed-bed bioreactors for solid-state fermentation. Process Biochem., 35, 167-178.

NRC (1989), Nutrient requirements of beef cattle. 4. ed. Washington : National Academy of Science (Nutrient requirements of domestic animals; 4).

Pandey, A.; Soccol, C. R.; Rodriguez-Leon, J. R. and Nigam, P. (2001), Solid - state fermentation in Biotechonogy: Fundamentals and applications. New Delhi : Asiatech Publishers. Inc.

Santos, M. V. F.; Lira. M. de A. and Farias, I. (1992), Efeito do período de armazenamento pós-colheita sobre o teor de matéria seca e composição química das palmas forrageiras. Pesq. Agrop. Bras., 27, 777-783.

Santos, M. V. F. (1989), Composição química, armazenamento e avaliação da palma forrageira (Opuntia ficus-indica Mill e Nopolea cocheniliifera Salm-Dyck) na produção de leite, em Pernambuco. MsC. Dissertation, UFRPE, Recife, PE, Brazil.

Sato, K. and Sudo, S. (1999), Small-scale solid-state fermentation. In: Demain, A. L. and Davies, J. E. (Eds.). Manual of industrial microbiology and biotechnology. 2. ed. pp. 61-79.
Silva, D. J. (1998), Análise de alimentos (Métodos quìmicos e Biológicos). 2. ed. Viçosa : Editora UFV.

Teixeira, J. C.; Evangelista, A. R.; Perz, J. R. O.; Trindade, I. A. C. M. and Moron, I. R. (1999), Cinética da digestão ruminal da palma forrageira. Ciênc. e Agrotec., 23, 179-18.

Villas Boas, S. G. and Esposito, E. (2000), Bioconversão do bagaço de maçã; enriquecimento nutricional utilizando fungos para produção de um alimento alternativo de alto valor agregado. Rev. Biotec., 38-42.
Received: September 29, 2004; Revised: February 25, 2005; Accepted: March 25, 2005. 